\title{
Hexavalent Uranium Diffusion into Soils from Concentrated Acidic and Alkaline Solutions
}

Tetsu K. Tokunaga ${ }^{a *}$, Jiamin Wan ${ }^{a}$, Jasquelin Pena ${ }^{b}$, Stephen R. Sutton ${ }^{c}$, and Matthew Newville ${ }^{c}$

${ }^{a}$ Lawrence Berkeley National Laboratory, Berkeley, CA 94720, USA

${ }^{b}$ University of California, Berkeley, CA 94720, USA

c University of Chicago, Chicago, IL 60637, USA

* corresponding author (510-486-7176, fax 510-486-7797, tktokunaga@lbl.gov)

\begin{abstract}
Uranium contamination of soils and sediments often originates from acidic or alkaline waste sources, with diffusion being a major transport mechanism. Measurements of $\mathrm{U}(\mathrm{VI})$ diffusion from initially $\mathrm{pH} 2$ and $\mathrm{pH} 11$ solutions into a slightly alkaline Altamont soil and a neutral Oak Ridge soil were obtained through monitoring uptake from boundary reservoirs and from $U$ concentration profiles within soil columns. The soils provided $\mathrm{pH}$ buffering, resulting in diffusion at nearly constant $\mathrm{pH}$. Micro x-ray absorption near edge structure spectra confirmed that $U$ remained in $U(V I)$ forms in all soils. Time trends of $\mathrm{U}(\mathrm{VI})$ depletion from reservoirs, and $\mathrm{U}(\mathrm{VI})$ concentration profiles within soil columns yielded $K_{d}$ values consistent with those determined in batch tests at similar concentrations $(\approx 1 \mathrm{mM})$, and much lower than values for sorption at much lower concentrations $(n M$ to $\mu M)$. These results show that $U(V I)$ transport at high concentrations can be relatively fast at non-neutral $\mathrm{pH}$, with negligible surface diffusion, because of weak sorption.
\end{abstract}

\section{Introduction}

Transport of uranium through soil and sediments is of great concern in regions affected by $U$ processing (mining, milling, refining, and waste disposal). While large-scale migration of $U$ contamination in the subsurface is determined by advection along permeable pathways connected to the waste source, its local distribution is diffusion controlled. The local impact of diffusion is especially important when large fractions of the subsurface have low hydraulic conductivities relative to a small fraction of interconnected preferential flow paths, and where hydraulic gradients are low. Environments contaminated by $U$ can be challenging to understand because of extreme disequilibrium, especially during early stages of contaminant transport. The potential extent of disequilibrium is evident when recognizing that waste solutions containing $U$ typically are either highly acidic or highly alkaline. Changes in $\mathrm{pH}$ encountered by waste solutions contacting soils, combined with very strong $\mathrm{pH}$ dependence of aqueous, sorbed, and solid $U$ species results in potentially complex series of $U$ transformations during transport (1). Because $U$ concentrations in both acidic and alkaline waste solutions from weapons processing can be very high (up to molar levels in extreme cases), experiments need to be conducted at elevated $U$ levels in order to understand transport through soils and sediments in regions near contaminant sources.

Considerable uncertainty on the extent of diffusive transport of $U$ can arise from geochemical factors. Precipitation-dissolution, sorption-desorption, and oxidationreduction reactions regulate aqueous and sorbed $U$ concentrations over many orders of 
magnitude. The concentration of aqueous phase $U$ depends strongly on its oxidation state $(\mathrm{U}(\mathrm{VI})$ versus $\mathrm{U}(\mathrm{IV}))$, solution $\mathrm{pH}$, sorption onto the solid phase, and solution complexes. The oxidized $\mathrm{U}(\mathrm{VI})$ species are often of greater interest in transport processes because they are commonly much more soluble and mobile than U(IV) species. Because $\mathrm{U}(\mathrm{VI})$ forms a variety of strongly $\mathrm{pH}$-dependent solution complexes and surface complexes, its sorption is strongly $\mathrm{pH}$-dependent, hence so is its mobility. Values of sorption partition coefficients $\left(K_{d}\right)$ can exceed $10^{4} \mathrm{~cm}^{3} \mathrm{~g}^{-1}$ in the neutral $\mathrm{pH}$ region, and fall below $10 \mathrm{~cm}^{3} \mathrm{~g}^{-1}$ under very acidic $(\mathrm{pH}<3)$ and alkaline $(\mathrm{pH}>9)$ conditions $(2,3)$. Like many other solutes, $\mathrm{U}(\mathrm{VI})$ sorption at any given $\mathrm{pH}$ is nonlinear, with strongest $\mathrm{U}(\mathrm{VI})$ sorption at low concentrations (4-6). Thus, $K_{d}$ values obtained from sorption experiments conducted in the $\mu \mathrm{M}$ range of $\mathrm{U}(\mathrm{VI})$ concentrations are not representative of sorption from more highly concentrated $U$ waste sources.

It has recently been shown that the presence of $\mathrm{Ca}^{2+}$ can dramatically alter $\mathrm{U}(\mathrm{VI})$ behavior through formation of the neutral $\mathrm{Ca}_{2} \mathrm{UO}_{2}\left(\mathrm{CO}_{3}\right)_{3}$ solution complex $(7,8)$. The environmental significance of this complex is just beginning to be recognized. The high stability of the aqueous $\mathrm{Ca}_{2} \mathrm{UO}_{2}\left(\mathrm{CO}_{3}\right)_{3}$ complex appears to be responsible for suppressing $\mathrm{U}(\mathrm{VI})$ sorption at circum-neutral $\mathrm{pH}(6)$, and strongly inhibits bacteria $\mathrm{U}(\mathrm{VI})$ reduction (9). For all of the aforementioned reasons, $\mathrm{U}(\mathrm{VI})$ sorption in a system experiencing large changes in $U$ concentration, $\mathrm{pH}$, and solution chemistry is complicated.

Despite the importance of $\mathrm{U}(\mathrm{VI})$ diffusion in contaminated soils, information was lacking on the early stages of this process in which either acidic or alkaline solutions containing high $U$ concentrations come in contact with soils. This study was designed to examine such conditions. Two different soil types, one neutral and the other slightly alkaline, were exposed to these acidic and alkaline $U(\mathrm{VI})$ solutions. The experiments presented here relied on characterizing spatial distributions of $\mathrm{U}(\mathrm{VI})$ during transient diffusion into soils and on measuring time trends in $\mathrm{U}(\mathrm{VI})$ depletion from boundary reservoirs. Before describing experimental procedures, a brief review of transient solute diffusion is presented to underscore the impact of sorption.

\section{Diffusion}

The diffusivity of $\mathrm{U}(\mathrm{VI})$ species in water is influenced by solution chemistry more than most ions because of its numerous aqueous complexes. However, relatively limited information on $\mathrm{U}(\mathrm{VI})$ aqueous diffusivities, $D_{o}$, is available in the literature. The $D_{0}$ values for the $\mathrm{UO}_{2}{ }^{2+}$ cation and various aqueous uranyl carbonate species at $21^{\circ} \mathrm{C}$ (our experimental conditions) were estimated as $6.1 \times 10^{-10}$ and $3.0( \pm 1.0) \times 10^{-10} \mathrm{~m}^{2} \mathrm{~s}^{-1}$ respectively, based on Millard and Hedges (10). The $D_{0}$ value for $\mathrm{UO}_{2}{ }^{2+}$ is applicable in dilute, acidic $(\mathrm{pH}<5)$ solutions where it is the dominant aqueous $\mathrm{U}(\mathrm{VI})$ species. The generic uranyl carbonate $D_{o}$ will be used in the neutral to alkaline range, to represent aqueous uranyl carbonates, $\left(\mathrm{UO}_{2}\right)_{2}(\mathrm{OH})_{3} \mathrm{CO}_{3}{ }^{-1}$, and $\mathrm{Ca}_{2} \mathrm{UO}_{2}\left(\mathrm{CO}_{3}\right)_{3}$ species that largely account for soluble $\mathrm{U}(\mathrm{VI})$ in waters equilibrated with atmospheric $\mathrm{CO}_{2}$. A large relative uncertainty was assigned to this generic uranyl carbonate $D_{0}$ because it represents a variety of solution species and because data on their individual $D_{0}$ are limited or lacking. Because $\left(\mathrm{UO}_{2}\right)_{2}(\mathrm{OH})_{3} \mathrm{CO}_{3}{ }^{-}, \mathrm{UO}_{2}\left(\mathrm{CO}_{3}\right)_{2}{ }^{2-}, \mathrm{UO}_{2}\left(\mathrm{CO}_{3}\right)_{3}{ }^{4-}$, and $\mathrm{Ca}_{2} \mathrm{UO}_{2}\left(\mathrm{CO}_{3}\right)_{3}$ are all assigned a common value of $D_{o}$, our diffusion calculations will be insensitive to uncertainties associated with speciation discussed later. The effective diffusivity of a 
solute in a saturated porous medium, $D_{e}$, is usually only associated with transport in the water-filled pores. Because the purely physical influences arise through pore structure controls on accessible diffusion paths, $D_{e}$ can be equated to the pore path diffusivity, $D_{e p}$, when surface diffusion is negligible. These diffusivities are related to the $D_{o}$ through

$$
D_{e} \approx D_{e p}=\Psi D_{o}
$$

where the diffusibility, $\Psi$, is a lumped dimensionless parameter that includes all pore structure influences (11). Although myriads of expressions for these physical influences have been proposed (e.g., 11-14), they are fairly well constrained by porosity, $n$. At $n=$ 0.50 , most expressions (11-14) lead to $\Psi=0.68 \pm 0.12$. In the absence of precipitated $\mathrm{U}(\mathrm{VI})$ phases (including suspended $\mathrm{U}$ colloids), the total local $\mathrm{U}(\mathrm{VI})$ concentration consists of this aqueous phase and an adsorbed phase, often approximately related through the linear partition relation

$$
C_{s}=K_{d} C
$$

where $C$ is the aqueous $\mathrm{U}(\mathrm{VI})$ mass per solution volume $\left[\mathrm{M} \mathrm{L}^{-3}\right]$, and $C_{s}$ is the sorbed $\mathrm{U}(\mathrm{VI})$ mass per solid phase mass $\left[\mathrm{M} \mathrm{M}^{-1}\right]$. In water-saturated soils with bulk density $\rho$ $\left[\mathrm{M} \mathrm{L}^{-3}\right]$, the solution and sorbed phase concentrations referenced to the soil bulk volume are $n C$ and $\rho K_{d} C$, respectively. Thus, the capacity is $n+\rho K_{d}$, which for nonsorbing solutes is simply equal to the porosity. Assuming $D_{e}, n, \rho_{\mathrm{b}}$, and $K_{d}$ are approximately constant within the saturated soil, Fick's $2^{\text {nd }}$ law takes the form

$$
\frac{\partial C}{\partial t}=\frac{D_{e}}{n+\rho_{b} K_{d}} \frac{\partial^{2} C}{\partial x^{2}}
$$

The ratio of effective diffusivity to capacity, $D_{e}\left(n+\rho_{\mathrm{b}} K_{d}\right)^{-1}$, is the apparent diffusivity $\left(D_{a}\right)$ that determines transient diffusion responses.

The dominant influence of sorption on transient diffusion of $\mathrm{U}(\mathrm{VI})$ becomes obvious in view of eq $3 a, b$ and typical magnitudes of $K_{d}$ reported in the literature $\left(10^{1}\right.$ to $10^{4} \mathrm{~cm}^{3} \mathrm{~g}^{-1}$ ). Thus, in the environmentally relevant $\mathrm{pH}$ range of 3 to $9, \rho K_{d}$ takes on values ranging from 10 to $10^{4}$ in soils, so that $\mathrm{U}(\mathrm{VI})$ sorption outweighs the influence of porosity by about 20 to $2 \times 10^{4}$ (given typical $n \approx 0.5$ ). Maximum sorption occurs in the neutral $\mathrm{pH}$ region, and declines sharply with increased acidity and alkalinity. Given the potentially large fraction of $\mathrm{U}(\mathrm{VI})$ occurring on sorption sites, it becomes reasonable to consider whether diffusion along grain surfaces is significant. The surface diffusivity $\left(D_{s}\right)$ can be introduced (e.g., 15) to obtain a more general expression for $D_{e}$ as

$$
D_{e}=D_{e p}+\rho_{b} K_{d} D_{s}
$$

Note that the pore path diffusivity $D_{e p}$ is equated with $D_{e}$ when $\rho_{\mathrm{b}} K_{d} D_{s}$ is negligible. Inclusion of $D_{s}$ leads to a more general expression for the apparent diffusivity 


$$
D_{a}=\frac{D_{e p}+\rho_{b} K_{d} D_{s}}{n+\rho_{b} K_{d}}
$$

However, experiments that have demonstrated surface diffusion are relatively few, and the phenomenon is sometimes invoked without sufficient evidence (16). Surface diffusion has been reported for $\mathrm{Cs}^{+}$in smectite clays $(17,18)$, and $\mathrm{Sr}^{2+}$ in smectites and granite (17-19). On the other hand, the results of Oscarson (15) indicate that surface diffusion has a relatively minor contribution for $\mathrm{Sr}^{2+}, \mathrm{Ca}^{2+}$, and $\mathrm{Na}^{+}$transport in smectite. To our knowledge, no studies have been published that evaluate the significance of $\mathrm{U}(\mathrm{VI})$ surface diffusion in soils. The present work relies on transient diffusion experiments in soils to determine $K_{d}$ and $D_{a}$ under contrasting $\mathrm{pH}$ conditions, and to evaluate the significance of the $\mathrm{U}(\mathrm{VI})$ surface diffusivity, $D_{s}$. Values of $K_{d}$ were also independently determined in batch equilibration measurements.

\section{Materials and Methods}

Soils and $\mathrm{U}(\mathrm{VI})$ solutions. Two different soil types were used, a slightly alkaline Altamont (AL) soil, and a neutral Oak Ridge (OR) sediment. The AL soil is from Altamont Pass (CA). Some basic properties of these soils are summarized in Table 1. The OR Nolichucky shale saprolite was obtained from U.S. Department of Energy, Natural and Accelerated Bioremediation Research (NABIR) Program's Background Area field site at Oak Ridge National Laboratory (TN). Samples were sieved $(2 \mathrm{~mm})$ and homogenized before packing into the diffusion cells.

$\mathrm{U}(\mathrm{VI})$ solutions were prepared by dissolving $\mathrm{UO}_{2}\left(\mathrm{NO}_{3}\right)_{2}$, and adjusting the $\mathrm{pH}$ to either 2.0 or 11.0 , using $\mathrm{HCl}$ or $\mathrm{NaOH}$, respectively. The final acidic and alkaline solutions both had $\mathrm{U}(\mathrm{VI})$ concentrations of $0.94 \mathrm{mM}\left(220 \mathrm{mg} \mathrm{L}^{-1}\right)$, and were in contact with the atmosphere $\left(\mathrm{P}_{\mathrm{CO} 2}=10^{-3.5} \mathrm{~atm}\right)$.

Diffusion cells and measurements. The soil column design is shown in Figure 1, and is similar to one used previously (20). Unlike the previous columns, these did not have a section of the wall removed and sealed with a Kapton film window for the x-ray measurements. Instead, one side of each $12.7 \mathrm{~mm}$ ID polycarbonate column was milled to provide a wall thickness of $1.0 \mathrm{~mm}$. The $\mathrm{e}^{-1}$ absorption depth for polycarbonate at the $U L_{\text {III }}$ edge is about $14 \mathrm{~mm}$, such that $x$-ray attenuation through the plastic window was negligible. Soils were homogeneously packed into the columns to a height of $62 \mathrm{~mm}$ and porosity of 0.50 , and then presaturated with solutions containing organic carbon at 0 or $80 \mathrm{mg} \mathrm{L}^{-1}$. Tryptic soy broth was used to prepare the organic carbon solutions, which served to establish slightly reducing conditions in some of the soils. The columns were maintained with these solutions under hydrostatic conditions for 30 days, after which they were replaced with $9.0 \mathrm{~mL}$ of either the $\mathrm{pH} 2 \mathrm{or} \mathrm{pH} 11 \mathrm{U}(\mathrm{VI})$ solutions. The vertically oriented columns were stored at room temperature in a plastic box that served as a secondary container in case of $U$ leakage. Because the top of the reservoir was kept vented to the atmosphere (constant $\mathrm{P}_{\mathrm{CO} 2}$ and $\mathrm{P}_{\mathrm{O} 2}$ ), evaporative water losses occurred over the 600 days of $U$ exposure. Losses from evaporation and sampling were compensated in most of the columns with periodic additions of distilled water, keeping the reservoir levels within $10 \%$ of their initial values. However, the $2 \mathrm{AL}$ soils exposed to initially acidic $U$ solutions were not maintained in this manner after they began leaking into the secondary container about midway through the experiment. Redox potential 
profiles within the soil columns were periodically measured using embedded $\mathrm{Pt}$ electrodes, with a calomel reference electrode temporarily placed in the boundary reservoir. The $\mathrm{pH}$ of the boundary reservoir in each column was measured periodically using a glass combination electrode. Uranium concentrations in the boundary reservoirs were determined by periodic sampling $(0.05$ to $0.10 \mathrm{~mL})$, and analysis by ICP and kinetic phosphorimetry (KPA, Chemchek, Richland, WA).

$X$-ray microprobe and micro-XANES spectroscopy. Profiles of the total $U$ and $U(V I)$ distribution within the sediment columns were obtained by $x$-ray microprobe and micro$x$-ray absorption near-edge structure (micro-XANES) spectroscopy, at the GSECARS beamline 13ID-C, Advanced Photon Source, Argonne National Laboratory (21). These measurements were obtained on days 150 and 600 relative to initial exposure to the $\mathrm{U}(\mathrm{VI})$ solutions. The $\mathrm{x}$-ray beam was defocused to provide a spot size of about $100 \mu \mathrm{m}$ (vertical) by $1,000 \mu \mathrm{m}$ (horizontal) on the vertically-oriented columns. Total $\mathrm{U}$ and $\mathrm{U}(\mathrm{VI})$ profiles were obtained by moving columns along the vertical direction in front of the stationary $x$-ray beam. At each measurement location, a micro-XANES spectrum was obtained by scanning the monochromator through several energies below, within, and above the $U_{\text {LIIII }}$ edge. Uranium $L_{\text {III }}$ edge positions were calibrated to $\mathrm{UO}_{2}\left(\mathrm{NO}_{3}\right)_{2}$ and $\mathrm{UO}_{2}$ for $\mathrm{U}(\mathrm{VI})$ and $\mathrm{U}(\mathrm{IV})$, respectively. These reagents were mixed into soil at concentrations ranging from 100 to $10,000 \mu \mathrm{g} \mathrm{g}^{-1}$, with the $\mathrm{U}(\mathrm{IV})$ standards prepared in a $\mathrm{N}_{2}$ environment. Total $U$ concentrations of unknowns were calculated based on comparing magnitudes of background-subtracted edge step heights to concentration standards $\left(\mathrm{UO}_{2}\left(\mathrm{NO}_{3}\right)_{2}\right.$ mixed into soils at concentrations ranging from 0 to $\left.5,000 \mathrm{mg} \mathrm{kg}^{-1}\right)$. The local oxidation state of $U$ in columns was calculated based on comparisons of energies at the edge half-height with those of the oxidation state standards (22).

Diffusion analyses. Fitting experimental results to model predictions allowed determination of $K_{d}$ values and evaluation of the significance of surface diffusivity, $D_{s}$. Because of periodic mixing (during $\mathrm{pH}$ and redox measurements, and sampling for $U$ analyses) of the reservoir solution, the experiment approximated 1-dimensional diffusion from a well-stirred finite reservoir into a finite soil column. Analytical solutions for concentrations in the reservoir $(23)$, and along the soil column $(24,25)$ were modified to include linear sorption. Finite difference calculations (23) were also done for comparisons with the analytical solutions. For the boundary reservoir, the timedependent relative concentration is given by

$$
\frac{C(t)}{C_{0}}=1-\frac{\left(n+\rho_{b} K_{d}\right) L}{a+\left(n+\rho_{b} K_{d}\right) L}\left\{1-\sum_{i=1}^{\infty} \frac{2 \alpha(1+\alpha)}{1+\alpha+\alpha^{2} q_{i}^{2}} \exp \left(\frac{-D_{a} q_{i}^{2} t}{L^{2}}\right)\right\}
$$

where $C_{o}$ is the initial reservoir $U$ concentration, $a$ is the reservoir height, $L$ is the soil column height, $\alpha$ is the equilibrium reservoir-soil partitioning equal to $a\left[\left(n+\rho_{\mathrm{b}} K_{d}\right) L J^{1}\right.$, and $q_{i}$ are the roots to

$$
\tan \left(q_{i}\right)=-\alpha q_{i}
$$

For small values of $D_{a} t L^{-2}$, the following simpler expression was used 


$$
\frac{C(t)}{C_{0}}=1-\frac{\left(n+\rho_{b} K_{d}\right) L}{a+\left(n+\rho_{b} K_{d}\right) L}(1+\alpha)\left\{1-\exp \left(\frac{D_{a} t}{\alpha^{2} L^{2}}\right) \operatorname{erfc}\left(\frac{D_{a} t}{\alpha^{2} L^{2}}\right)^{1 / 2}\right\}
$$

Within the soil column, the aqueous phase concentration is given by

$$
C(x, t)=\frac{a C_{o}}{a+\left(n+\rho_{b} K_{d}\right) L}+\frac{C_{o}}{a} \sum_{i=1}^{\infty} \frac{2\left(n+\rho_{b} K_{d}\right) \cos \left(\beta_{i} x\right) \exp \left(\frac{-D_{a} \beta_{i}^{2} t}{n+\rho_{b} K_{d}}\right)}{\cos \left(\beta_{i} L\right)\left\{\left[\beta_{i}^{2}+\left(\frac{n+\rho_{b} K_{d}}{a}\right)^{2\rceil}\right]+\left(\frac{n+\rho_{b} K_{d}}{a}\right)\right\}}
$$

where $x=0$ at the impermeable bottom boundary, $x=L$ at the soil-reservoir interface, and $\beta_{i}$ are the roots to

$$
\beta_{i} L \cot \left(\beta_{i} L\right)=-\frac{\left(n+\rho_{b} K_{d}\right) L}{a}
$$

The total $U(\mathrm{VI})$ concentration profiles $\left(C_{\Sigma}(x, t)\right)$ are then obtain from combining (9) and (2). Fitting measurements of reservoir $C(t)$ and soil $C_{\Sigma}(x, t)$ to calculations permit comparisons between $D_{a}$ obtained from the response of different compartments of the same system. In actual analyses, $K_{d}$ became the only adjustable parameter because inclusion of $D_{s}$ never improved fits.

\section{Results and Discussion}

Reservoir $\mathrm{pH}$ and $\mathrm{U}$ speciation. The $\mathrm{pH}$ in the boundary reservoir solutions of the $\mathrm{AL}$ and $\mathrm{OR}$ soils prior to exposure to the $\mathrm{U}(\mathrm{VI})$ solutions were in the ranges of $6.5 \pm 0.3$ and $7.7 \pm 0.5$, respectively. Upon switching to the acidic $(\mathrm{pH} 2)$ and alkaline $(\mathrm{pH} 11) \cup(\mathrm{VI})$ solutions, neutralization of the initially extreme $\mathrm{pH}$ values occurred to varying extents (Figure 2, with +0 and +80 denoting $\mathrm{mg} \mathrm{L}^{-1}$ of organic carbon in the soil pore waters prior to U-exposure). For the OR soil exposed to the alkaline $\mathrm{U}(\mathrm{VI})$ solution, and all $\mathrm{AL}$ soils, neutralization was completed within 10 days, and longer term $\mathrm{pH}$ remained within $1 \mathrm{pH}$ unit of pre-exposure values. The $\mathrm{OR}$ soil exposed to the $\mathrm{pH} 2 \mathrm{U}(\mathrm{VI})$ solution increased to $\mathrm{pH} 4 \pm 0.4$ by day 70 , and stayed in this range for the remainder of the experiment. The relatively rapid stabilization of $\mathrm{pH}$ values in the reservoirs indicated that individual systems could be approximated as having constant $K_{d}$ during $\mathrm{U}(\mathrm{VI})$ diffusion, especially in the calcite-buffered AL soils. Reservoir solution chemistry data for the acidic $A L+0$ and $A L+80$ soil columns are not available after day 150 and 250, respectively, because of solution levels were not maintained. As shown later, the $\mathrm{pH}$ history has a significant influence on $\mathrm{U}(\mathrm{VI})$ diffusion.

Although individual columns exhibited considerable variation in redox potentials (typically $\pm 100 \mathrm{mV}$ at any given time), they reflected oxidizing conditions immediately prior to the time of $\mathrm{U}(\mathrm{VI})$ exposure. Column-average redox potential measurements ranged from +300 to $+500 \mathrm{mV}$ (relative to the standard $\mathrm{H}$ electrode) before contact with $\mathrm{U}(\mathrm{VI})$ solutions, and did not exhibit any systematic decreases throughout the remainder 
of the experiment. In contrast, similar soils treated with higher levels of organic carbon did show substantial decreases in redox potentials, and micro-XANES measurements did confirm $U$ reduction in these other systems (unpublished). Thus, the redox potential measurements provided indirect evidence that $\mathrm{U}(\mathrm{VI})$ reduction did not occur in the diffusion experiments reported here.

The $\mathrm{pH}$ values associated with reservoir $U$ measurements need to be considered in order to identify dominant $U$ species in each system. Combining the previously shown $\mathrm{pH}$ time trends with their associated $U$ levels lead to reservoir $\mathrm{U}(\mathrm{pH}$ ) relations (Figure 3 ). Time is implicit in these relations, with the initial states associated with maximum $U$. Included in this figure is the estimated $\mathrm{pH}$-dependence of $\mathrm{U}(\mathrm{VI})$ solubility, calculated with MINEQL+ (26), using formation constants from Guillaumont et al. (27) and Bernhard et al. (8). Speciation and total soluble $U$ concentrations were calculated without and with equilibrium with respect to calcite because it is a major phase in the AL soil, but not in the OR soil. In view of questions concerning the magnitude of the formation constant for $\mathrm{Ca}_{2} \mathrm{UO}_{2}\left(\mathrm{CO}_{3}\right)_{3}$ raised by Guillaumont et al. (27), the calculated solubility of $\mathrm{U}(\mathrm{VI})$ in equilibrium with calcite is taken as an upper limit for this condition. Measured $\mathrm{U}(\mathrm{pH})$ values that plot above the appropriate soluble $U$ curve indicate that precipitation of schoepite is favored. Comparisons between measurements and calculations show that (i) the initially acidic $U$ solution diffusing into the AL soil is temporarily supersaturated while crossing over neutral $\mathrm{pH}$, before becoming more alkaline, (ii) the initially acidic $U$ solution diffusing into the $O R$ soil remains in soluble forms, (iii) the initially alkaline $U$ solution diffusing into the $A L$ soil quickly reaches $\mathrm{pH} \approx$ 8.1 while remaining undersaturated, and (iv) the initially alkaline $U$ solution diffusing into the OR soil quickly becomes supersaturated during neutralization. One data point for the alkaline $A L+0$ system has an uncertain $\mathrm{pH}$ value, identified by the question mark in Figure 3. All other $\mathrm{pH}$ measurements on that system were high enough to indicate that $\mathrm{U}(\mathrm{VI})$ remained in solution. It is worth noting that significant $\mathrm{U}(\mathrm{VI})$ supersaturation has been observed to persist for over 30 days, and that supersaturation in general is not proof for precipitation $(28,29)$. Data presented later indicate that $\mathrm{U}(\mathrm{VI})$ precipitation did not occur. The presence of calcite is predicted to have a strong influence on $U$ solubility in the $\mathrm{AL}$ systems because of $\mathrm{Ca}_{2} \mathrm{UO}_{2}\left(\mathrm{CO}_{3}\right)_{3}$ formation, based on its reported stability (8), but the magnitude of this effect remains to be determined (27). In the initially acidic solutions, calcite rapidly buffered the reservoir to $\mathrm{pH} \approx 8$, and $\mathrm{Ca}^{2+}$ levels are predicted to enhance $\mathrm{U}(\mathrm{VI})$ solubility through formation of aqueous $\mathrm{Ca}_{2} \mathrm{UO}_{2}\left(\mathrm{CO}_{3}\right)_{3}$. Similar effects apply for the alkaline $U$ solution exposed to the $A L$ soil, although slightly high equilibrium $\mathrm{pH}$ and presumably slightly lower $\mathrm{Ca}^{2+}$ concentrations are attained. Calculated dominant species of $\mathrm{U}(\mathrm{VI})$ in the various diffusing solutions are summarized in Table 2. Choices of $D_{o}$ values applied to calculations on each system were based on calculated $\mathrm{U}(\mathrm{VI})$ speciation as described previously.

Time trends for reservoir $U$ concentrations. Total $U$ concentrations in the boundary reservoirs declined monotonically with time (Figure 4). The linear, reversible sorption approximation to the diffusion process (eq 6 and 8) was fit to the data for comparison, with some results included in Figure 4. Given that inclusion of finite $D_{s}$ contributions to $D_{a}$ never improved agreements between model predictions and the data, we conclude that surface diffusion is not important in our systems. Thus, $K_{d}$ served as the only adjustable parameter in the model time trends. The levels indicated along the right axis 
of each plot in Figure 4 are the first 2 terms in eq 6 (i.e., when the summation over exponential terms becomes negligible), and denote predicted solution concentrations upon reaching equilibrium, assuming the specified $K_{d}$ values. Fairly good fits were obtained for the AL soils (Figures $4 \mathrm{a}$ and $4 \mathrm{~b}$ ) using $K_{d}=4 \mathrm{~cm}^{3} \mathrm{~g}^{-1}$ for the initially acidic systems (quickly buffered to $\mathrm{pH} 8.0 \pm 0.5$ ), and $K_{d}=6 \mathrm{~cm}^{3} \mathrm{~g}^{-1}$ for the initially alkaline systems (quickly buffered to $\mathrm{pH} 8.1 \pm 0.5$ ). Independently measured batch $K_{d}$ values at $\mathrm{pH} 8.0$ ranged from 6.5 to $2.7 \mathrm{~cm}^{3} \mathrm{~g}^{-1}$, over a similar solution $\mathrm{U}(\mathrm{VI})$ concentration range $(0.05$ to $0.24 \mathrm{mM})$. It should be noted that these $K_{d}(\mathrm{pH})$ values are much lower than those commonly reported for $\mathrm{U}(\mathrm{VI})$ sorption on soils, reflecting weaker sorption with higher loading. Batch determinations of $K_{d}$ for $\mu \mathrm{M}$ levels of $\mathrm{U}(\mathrm{VI})$ equilibrated with $\mathrm{AL}$ soils $(\mathrm{pH} 8.0)$ yielded values of about $20 \mathrm{~cm}^{3} \mathrm{~g}^{-1}$ (6). Even these latter values are still much lower than $K_{d}$ values obtained at $\mathrm{pH} 8.0$ in other soils (e.g., 2,3), apparently because of the high $\mathrm{CaCO}_{3}$ content in the $\mathrm{AL}$ soils (10\%) and the stability of aqueous $\mathrm{Ca}_{2} \mathrm{UO}_{2}\left(\mathrm{CO}_{3}\right)_{3}$.

Unlike the $\mathrm{AL}$ soils, the time trends for $\mathrm{U}(\mathrm{VI})$ removal from reservoirs in contact with the OR soils were not as amenable to representation by constant $K_{d}$ values. Instead, the OR systems responded as if $K_{d}$ values progressively increase over time. Although the acidic OR systems (Figure 4c) remained undersaturated with respect to schoepite such that simple diffusion with reversible sorption-desorption might be assumed, possible coprecipitation cannot be ruled out (29). Despite the poor fit to acidic OR reservoir $U$ concentrations obtained with any single $K_{d}$, a value of $20 \mathrm{~cm}^{3} \mathrm{~g}^{-1}$ yielded a fair fit to the soil concentration profile data described in the next section. For comparison, batch-based $K_{d}$ values of 76 and $35 \mathrm{~cm}^{3} \mathrm{~g}^{-1}$ were obtained for the OR soil $(\mathrm{pH} 4.1)$ in equilibrium with 0.10 and $0.53 \mathrm{mM} \mathrm{U}(\mathrm{VI})$. At much lower $(\mu \mathrm{M})$ concentrations, sorption experiments on this $\mathrm{OR}$ soil at $\mathrm{pH} 4$ yielded $K_{d} \approx 100 \mathrm{~cm}^{3} \mathrm{~g}^{-1}$ (6).

The time trends in initially alkaline $U$ solutions placed in contact with the OR soils were very poorly represented by diffusion with constant $K_{d}$ (Figure $4 d$ ). As noted previously, these initially alkaline $\mathrm{U}(\mathrm{VI})$ solutions became supersaturated with respect to schoepite shortly after exposure to the OR soils so that concentration time trends probably reflect combined influences of precipitation-dissolution, sorption-desorption, and diffusion.

$U$ diffusion profiles in soil columns. Profiles of total $U$ concentrations in the soil columns obtained with the x-ray microprobe are shown in Figure 5. Micro-XANES spectra confirmed that $U$ remained in hexavalent forms, within measurement uncertainty (about $\pm 10 \%$ ). The soils pretreated with +0 and $+80 \mathrm{mg} \mathrm{L}^{-1}$ organic carbon solutions exhibited practically the same $U$ profiles, so that only the systems without organic carbon addition are shown for most cases. However, for the AL soils initially exposed to $\mathrm{pH} 2 \mathrm{U}(\mathrm{VI})$ solutions, only the $+80 \mathrm{mg} \mathrm{L}^{-1}$ organic carbon is shown because it was maintained longer than its the $+0 \mathrm{mg} \mathrm{L}^{-1}$ organic carbon counterpart. The day $150 \mathrm{U}$ profiles are incomplete, especially for the AL soils, because short diffusion distances were originally anticipated based on assumed larger $K_{d}$ values. Calculated total $U$ profiles are also shown in Figure 5, for comparison with each profile. These calculated $U$ profiles were obtained using $K_{d}$ values of equal or similar magnitude to those inferred from their associated reservoir $U$ time trends (Figure 4). Fits were obtained by adjusting $K_{d}$ values to minimize differences between model predictions (eq 9) and data for day 
150. These $K_{d}$ values were then used to calculate day 600 profiles in order to test predictability of later conditions. Generally good agreement is obtained between $K_{d}$ values inferred from reservoir $U$ concentration time trends and soil column $U$ profiles in the initially acidic and initially alkaline AL systems. Again, $U$ diffusion within the AL soils is best described by very low $K_{d}$ values. Uranium diffusion profiles were fairly well matched in the acidic OR soil with a $K_{d}=20 \mathrm{~cm}^{3} \mathrm{~g}^{-1}$, despite the less satisfactory fit of its reservoir $U$ concentration time trends. With the exception of the OR soils exposed to $\mathrm{pH} 11 \mathrm{U}$ solutions, the day $600 \mathrm{U}(\mathrm{VI})$ concentration profiles were fairly well predicted based on $K_{d}$ values obtained at day 150 . The OR soils exposed to alkaline $U$ solutions exhibited the shortest diffusion distances (Figure $5 \mathrm{~d}$ ), reflecting the combined influences of high sorption and precipitation. The poor day 600 fit obtained with $K_{d}=2,000 \mathrm{~cm}^{3} \mathrm{~g}^{-1}$ (obtained by fitting day 150 data) shows that this system cannot be describe simply by diffusion and sorption-desorption alone, and is consistent with precipitation having a strong influence.

These diffusion experiments yielded several insights into $U$ transport in soils. Although exposed to initially $\mathrm{pH} 2$ or $\mathrm{pH} 11 \mathrm{U}(\mathrm{VI})$ solutions, strong buffering by the soils (especially the calcareous $\mathrm{AL}$ soils) resulted in diffusion at nearly constant $\mathrm{pH}$ after short neutralization periods. Time trends of $\mathrm{U}(\mathrm{VI})$ depletion from reservoirs and $\mathrm{U}(\mathrm{VI})$ profiles within soil columns generally yielded similar $D_{a}$ and $K_{d}$ values. The $K_{d}$ values inferred from the diffusion experiments were in fair agreement with batch $K_{d}$ values obtained at similar concentrations $(0.05$ to $0.5 \mathrm{mM} \mathrm{U}(\mathrm{VI}))$, but were much lower than literature values obtained in the $\mathrm{nM}$ to $\mu \mathrm{M}$ range, reflecting nonlinearity in sorption. Diffusion of $\mathrm{U}(\mathrm{VI})$ into the calcareous $\mathrm{AL}$ soil is relatively efficient regardless of the initial solution $\mathrm{pH}$, probably because of the stability of aqueous $\mathrm{Ca}_{2} \mathrm{UO}_{2}\left(\mathrm{CO}_{3}\right)_{3}$ and consequent weaker sorption in these calcite-buffered systems. Diffusion into the OR soil under acidic conditions was also significantly faster than expected from sorption data obtained at lower concentrations. The initially alkaline $\mathrm{U}(\mathrm{VI})$ solution diffusing into the OR soil quickly stabilized at neutral $\mathrm{pH}$, such that precipitation prevented analysis of this system strictly in terms of diffusion and sorption. Inclusion of surface diffusion was unnecessary in any of these systems, but may be important for $\mathrm{U}(\mathrm{VI})$ diffusion at low concentrations and neutral $\mathrm{pH}$, where sorption is strongest.

\section{Acknowledgments}

We thank Keith Olson and Andrew Mei of LBNL, and GSECARS staff for technical assistance, and Robert Silva and Richard Wilson (LBNL) for providing information on $U$ solubilities in preliminary experiments. Helpful review comments by 3 anonymous reviewers and Zuoping Zheng (LBNL, on the original manuscript) are gratefully acknowledged. Funding for this study was provided through the U. S. Department of Energy, Basic Energy Sciences, Geosciences Program, and the Natural and Accelerated Bioremediation Research (NABIR) Program, under contract No. DE-AC0376SF00098. Portions of this work were performed at GeoSoilEnviroCARS (Sector 13), Advanced Photon Source (APS), Argonne National Laboratory. GeoSoilEnviroCARS is supported by the National Science Foundation - Earth Sciences (EAR-0217473), Department of Energy - Geosciences (DE-FG02-94ER14466) and the State of Illinois. Use of the APS was supported by the U.S. Department of Energy, Basic Energy Sciences, Office of Energy Research, under Contract No. W-31-109-Eng-38. 


\section{Literature Cited}

1. Langmuir, D. Aqueous Environmental Geochemistry; Prentice Hall: Upper Saddle River, 1997.

2. Waite, T. D.; Davis, J. A.; Fenton, B. R.; Payne, T. E. Radiochim. Acta 2000, 88, 687-693.

3. Barnett, M. O.; Jardine, P. M.; Brooks, S. C. Environ. Sci. Technol. 2002, 36, 937-942.

4. Barnett, M. O.; Jardine, P. M., Brooks, S. C.; Selim, H. M. Soil Sci. Soc. Am. J. 2000, 64, 908-917.

5. Gadelle, F.; Wan, J.; Tokunaga, T. K. J. Environ. Qual. 2001, 30, 470-478.

6. Zheng, Z.; Tokunaga, T. K.; Wan. J. Environ. Sci. Technol. 2003, 37, 5603-5608.

7. Bernhard, G.; Geipel, G.; Brendler, V.; Nitsche, H. Radiochim. Acta 1996, 74, 8791.

8. Bernhard, G.; Geipel, G.; Reich, T.; Brendler, V.; Amayri, S.; Nitsche, H. Radiochim. Acta 2001, 89, 511-518.

9. Brooks, S. C.; Fredrickson, J. K.; Carroll, S. L.; Kennedy, D. W.; Zachara, J. M.; Plymale, A. E.; Kelly, S. D.; Kemner, K. M.; Fendorf, S. Environ. Sci. Technol. 2003, 37, 1850-1858.

10. Millard, A. R.; Hedges, R. E. M. Geochim. Cosmochim. Acta 1996, 60, 21392152.

11.van Brakel, J.; Heertjes, P. M. Int. J. Heat Mass Transfer 1974, 17, 1093-1103.

12. Troeh, F. R.; Jabro, J. D.; Kirkham, D. Geoderma 1982, 27, 239-253.

13. Iversen, N.; Jorgensen, B. B. Geochim. Cosmochim. Acta 1993, 57, 571-578.

14. Olesen T.; Moldrup, P.; Henriksen, K.; Petersen, L. W. Soil Sci. 1996, 161, 633645.

15. Oscarson, D. W. Clays Clay Minerals 1994, 42, 534-543.

16. Cussler, E. L. Diffusion: Mass Transfer in Fluid Systems; Cambridge University Press: Cambridge, 1984.

17. Muurinen, A.; Rantanen, J.; Penttila-Hiltunen, P. Mat. Res. Soc. Symp. Proc. 1985, 50, 617-624.

18. Jensen, D. J.; Radke, C. J. J. Soil Sci. 1988, 39, 53-64.

19. Yamaguchi, T.; Sakamoto, Y.; Senoo, M. J. Nucl. Sci. Technol. 1993, 30, 796803.

20. Tokunaga, T. K.; Wan, J.; Firestone, M. K.; Hazen, T. C.; Olson, K. R.; Herman, D. J.; Sutton, S. R.; Lanzirotti, A. J. Environ. Qual. 2003, 32, 1641-1649.

21. Bertsch, P. M.; Hunter, D. B. Chem. Rev. 2001, 101, 1809-1842.

22. Duff, M. C.; Morris, D. E.; Hunter, D. B.; Bertsch, P. M. Geochim. Cosmochim. Acta 2000, 64, 1535-1550.

23. Crank, J. The Mathematics of Diffusion, $2^{\text {nd }}$ edition; Clarendon: Oxford, 1975.

24. Carslaw, H. S.; Jaeger, J. C. Conduction of Heat in Solids, $2^{\text {nd }}$ edition; Oxford University Press: London, 1959.

25. Tokunaga, T. K.; Waldron, L. J.; Nemson, J. Soil Sci. Soc. Am. J. 1988, 52, 1723.

26. Schecher, W. D.; McAvoy, D. C. MINEQL+, version 4.5. Environmental Research Software: Hallowell, ME, 2001. 
27. Guillaumont, R.; Fanghanel, T.; Fuger, J.; Grenthe, I.; Neck, V.; Palmer, D. A..; Rand, M. H.; Mompean, F. J.; Illemassene, M.; Domenechi-Orti, C. Update on the Chemical Thermodynamics of Uranium, Neptunium, Plutonium, Americium, and Technicium. Elsevier: Amsterdam, 2003.

28. Giammar, D. E.; Hering, J. G. Environ. Sci. Technol. 2001, 35, 3332-3337.

29. Sposito, G. The Surface Chemistry of Soils; Oxford University Press: New York, 1984. 
Table 1. Properties of the Oak Ridge and Altamont soils used in the experiments. Additional details are available in Zheng et al. (6).

\begin{tabular}{|c|c|c|c|}
\hline & units & Altamont & Oak Ridge \\
\hline sand & mass \% & 10 & 45 \\
\hline silt & mass \% & 62 & 43 \\
\hline clay & mass \% & 28 & 12 \\
\hline calcium carbonate equivalent & mass $\%$ & 10 & 0.1 \\
\hline Total Fe (XRF) & mass \% & 4.5 & 4.6 \\
\hline $0.5 \mathrm{M} \mathrm{HCl}$ extractable $\mathrm{Fe}$ & mass $\%$ & 0.24 & 0.37 \\
\hline $\mathrm{pH}$ (pore water prior to $U$ exposure) & & $8.0 \pm 0.2$ & $6.2 \pm 0.5$ \\
\hline electrical conductivity (1:1 water/soil) & $\mu S \mathrm{~cm}^{-1}$ & 300 & 30 \\
\hline $\mathrm{Ca}^{2+} \quad(1: 1$ water/soil $)$ & $\mathrm{mM}_{\mathrm{c}}$ & 1.65 & 0.19 \\
\hline $\mathrm{Mg}^{2+}$ (1:1 water/soil) & $\mathrm{mM}_{\mathrm{C}}$ & 1.13 & 0.04 \\
\hline $\mathrm{Na}^{+} \quad(1: 1$ water/soil $)$ & $\mathrm{mM}_{\mathrm{c}}$ & 0.33 & 0.11 \\
\hline $\mathrm{K}^{+} \quad(1: 1$ water/soil $)$ & $\mathrm{mM}_{\mathrm{c}}$ & 0.04 & 0.01 \\
\hline $\mathrm{SO}_{4}{ }^{2-}$ (1:1 water/soil) & $\mathrm{mM}_{\mathrm{c}}$ & 0.11 & 0.06 \\
\hline $\mathrm{HCO}_{3}^{-}$(1:1 water/soil) & $\mathrm{mM}_{\mathrm{c}}$ & 1.68 & 0.15 \\
\hline $\mathrm{Cl}^{-}(1: 1$ water/soil $)$ & $\mathrm{mM}_{\mathrm{c}}$ & 0.24 & 0.08 \\
\hline $\mathrm{NO}_{3}^{-}$(1:1 water/soil) & $\mathrm{mM}_{\mathrm{c}}$ & 1.29 & 0.08 \\
\hline
\end{tabular}


Table 2. Calculated $U$ speciation in reservoir solutions, and assumed aqueous phase diffusivities. Uncertainties in speciation reflect discussions of $\mathrm{Ca}_{2} \mathrm{UO}_{2}\left(\mathrm{CO}_{3}\right)_{3}$ in Guillaumont et al. (27).

\begin{tabular}{|c|c|c|c|c|c|}
\hline soil & & AL-2 & OR-2 & $A L-11$ & OR-11 \\
\hline initial reservoir $\mathrm{pH} \quad\left(\mathrm{pH}_{\mathrm{o}}\right)$ & & 2.0 & 2.0 & 11.0 & 11.0 \\
\hline characteristic reservoir $\mathrm{pH}$ & & 8.0 & 3.9 & 8.1 & 7.0 \\
\hline U supersaturated? & & no & no & no & yes \\
\hline $\mathrm{UO}_{2}{ }^{2+}$ & fraction & & 0.82 & & \\
\hline $\mathrm{UO}_{2} \mathrm{NO}_{3}^{+}$ & “ & & 0.06 & & \\
\hline $\mathrm{UO}_{2}$ hydroxides & “ & & 0.12 & & 0.08 \\
\hline$\left(\mathrm{UO}_{2}\right)_{2}(\mathrm{OH})_{3} \mathrm{CO}_{3}^{-}$ & “ & $\geq 0.06$ & & $\geq 0.06$ & 0.88 \\
\hline $\mathrm{UO}_{2} \mathrm{CO}_{3}$ & “ & & & & 0.02 \\
\hline $\mathrm{UO}_{2}\left(\mathrm{CO}_{3}\right)_{2}{ }^{2-}$ & “ & $\geq 0.02$ & & $\geq 0.03$ & 0.02 \\
\hline $\mathrm{UO}_{2}\left(\mathrm{CO}_{3}\right)_{3}{ }^{4-}$ & “ & 0.04 & & 0.10 & \\
\hline $\mathrm{Ca}_{2} \mathrm{UO}_{2}\left(\mathrm{CO}_{3}\right)_{3}$ & “ & $\leq 0.88$ & & $\leq 0.81$ & \\
\hline assumed $D_{0}$ & $m^{2} s^{-1}$ & $3 \times 10^{-10}$ & $6 \times 10^{-10}$ & $3 \times 10^{-10}$ & $3 \times 10^{-10}$ \\
\hline
\end{tabular}




\section{Figure Captions}

Figure 1. Diffusion cell. (a) soil column. (b) boundary $U$ reservoir. (c) x-ray window. (d) soil-reservoir connection. (e) Pt redox electrode. (f) bottom plug. (g) O-ring seals. (h) top cap. (i) incident $x$-ray beam. (j) fluorescence $x$-rays.

Figure 2. Reservoir $\mathrm{pH}$ trends in soils exposed to $\mathrm{U}(\mathrm{VI})$ solutions with (a) initial $\mathrm{pH}=$ 2.0, and (b) initial $\mathrm{pH}=11.0$.

Figure 3. Reservoir $\mathrm{U}(\mathrm{pH})$ trends in the initially (a) acidic, and (b) alkaline solutions. Time is associated with generally decreasing $U$ concentrations. Also shown is the calculated $\mathrm{pH}$-dependence of $\mathrm{U}$ solubility (at $\mathrm{PCO}_{2}=10^{-3.5} \mathrm{~atm}$ ) without and with equilibrium with respect to calcite.

Figure 4. Time trends for reservoir $U$ concentrations. Individual graphs are for (a) Altamont soil with $\mathrm{pH}_{\circ} 2.0$, (b) Altamont soil with $\mathrm{pH}_{\circ} 11.0$, (c) Oak Ridge soil with $\mathrm{pH}_{\circ}$ 2.0, and (d) Oak Ridge soil with $\mathrm{pH}_{\mathrm{o}}$ 11.0. Curves are fits to eq 6 and 8.

Figure 5. $\mathrm{U}(\mathrm{VI})$ concentration profiles within soil columns at 150 and 600 days, along with fits to eq 9. Individual graphs are for (a) Altamont soil with $\mathrm{pH}_{\mathrm{o}} 2.0$, (b) Altamont soil with $\mathrm{pH}_{\circ}$ 11.0, (c) Oak Ridge soil with $\mathrm{pH}_{\circ} 2.0$, and (d) Oak Ridge soil with $\mathrm{pH}_{\circ} 11.0$. 


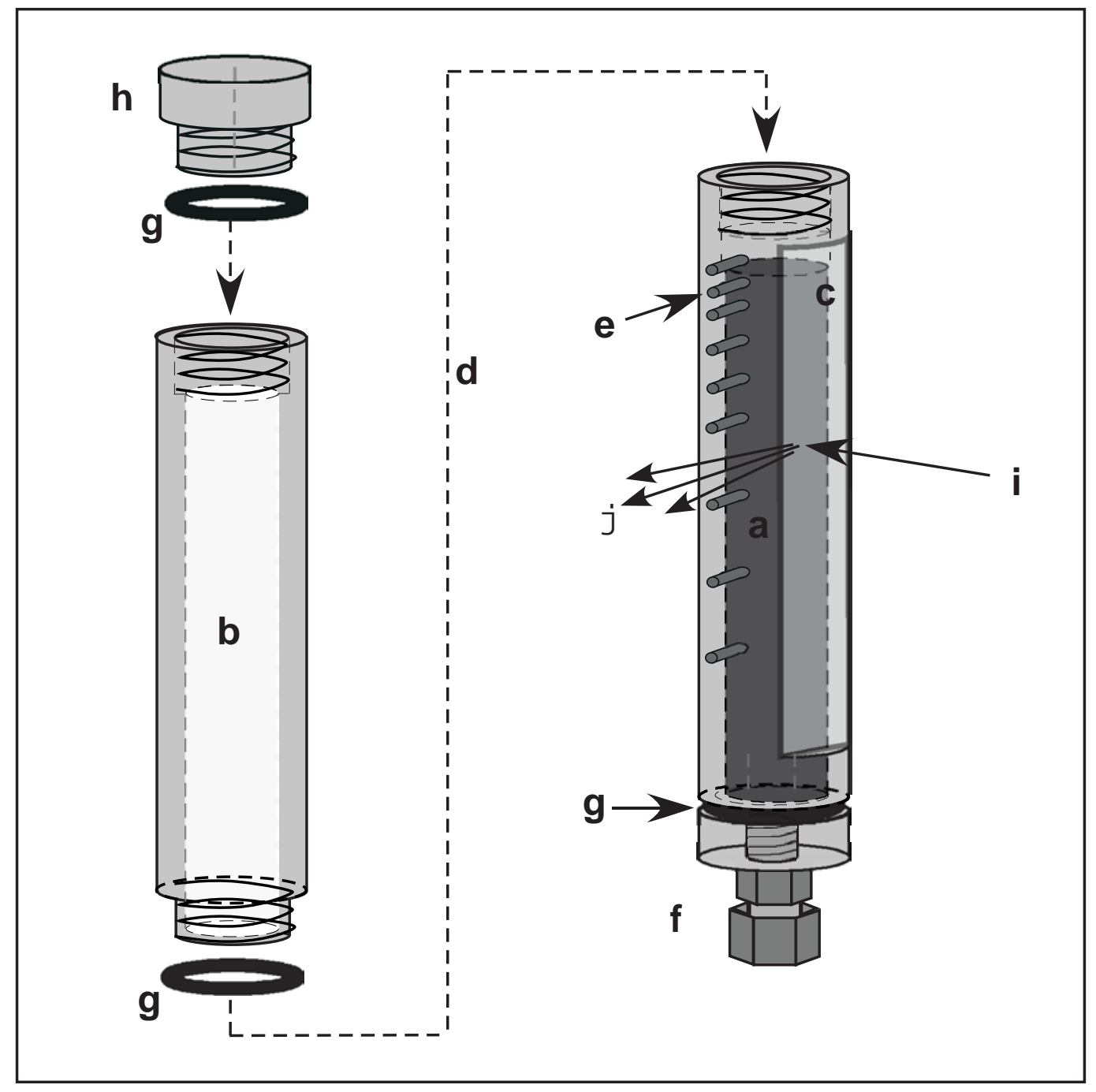

Figure 1. Diffusion cell. (a) soil column. (b) boundary $U$ reservoir. (c) x-ray window. (d) soil-reservoir connection. (e) Pt redox electrode. (f) bottom plug. (g) O-ring seals. (h) top cap. (i) incident $x$-ray beam. (j) fluorescence x-rays. 


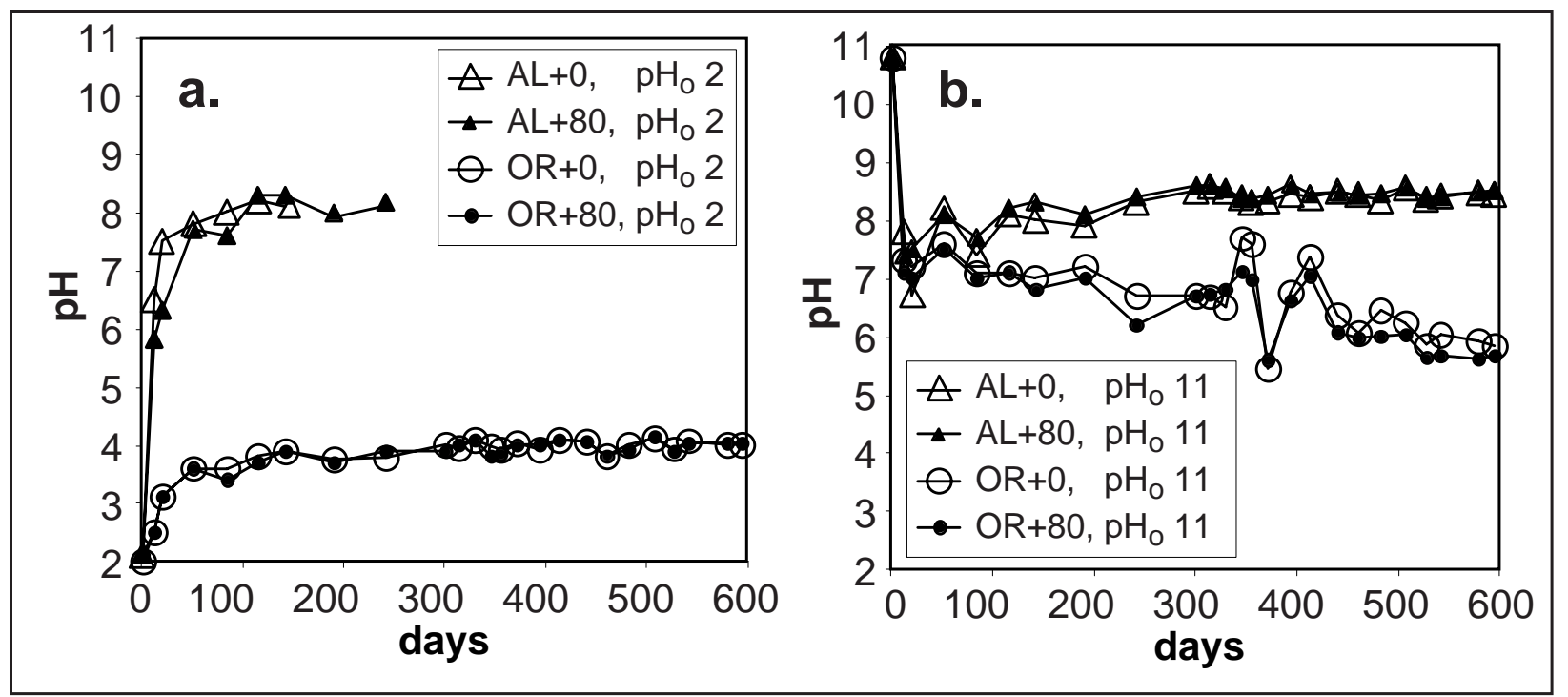

Figure 2. Reservoir $\mathrm{pH}$ trends in soils exposed to $\mathrm{U}(\mathrm{VI})$ solutions with (a) initial $\mathrm{pH}=$ 2.0, and (b) initial $\mathrm{pH}=11.0$.

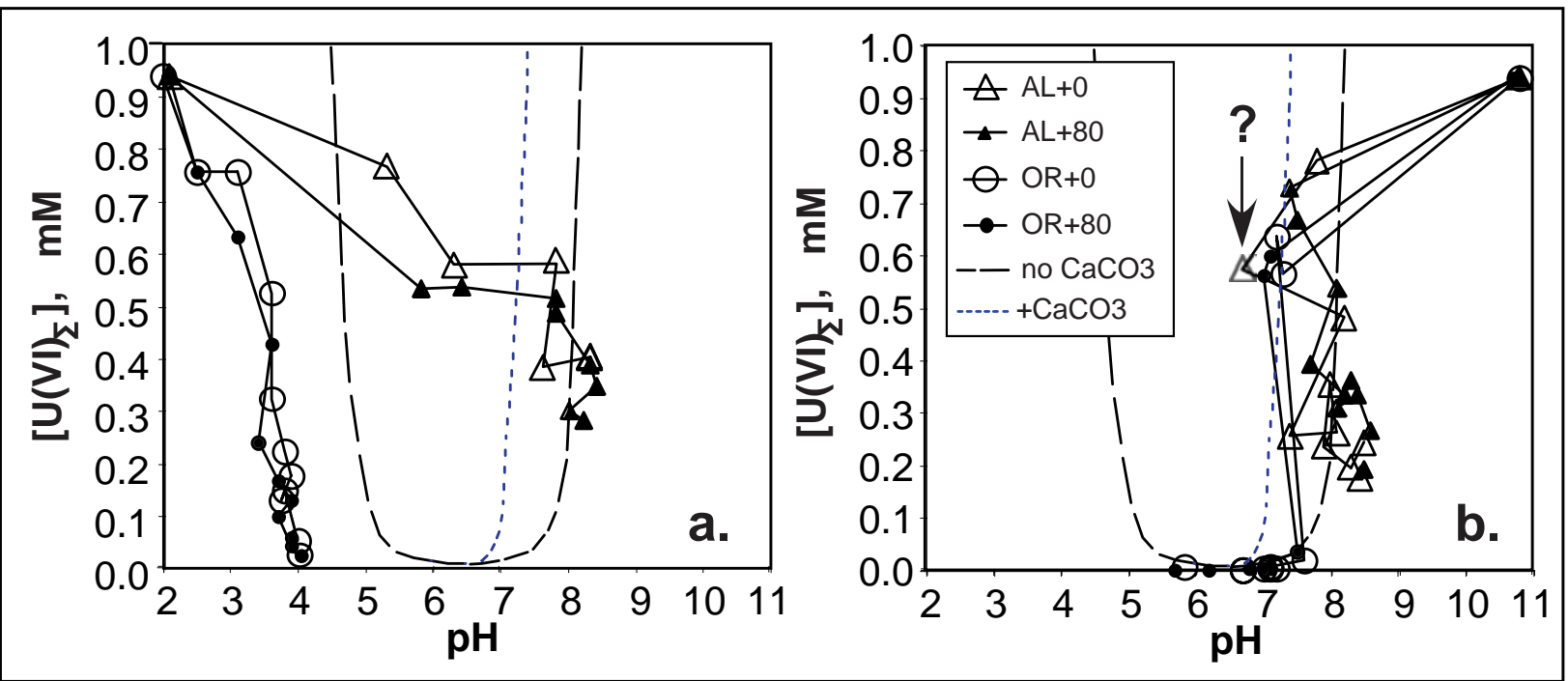

Figure 3. Reservoir $U(\mathrm{pH})$ trends in the initially (a) acidic, and (b) alkaline solutions. Time is associated with generally decreasing $U$ concentrations. Also shown is the calculated $\mathrm{pH}$-dependence of $U$ solubility without and with equilibrium with respect to calcite. 

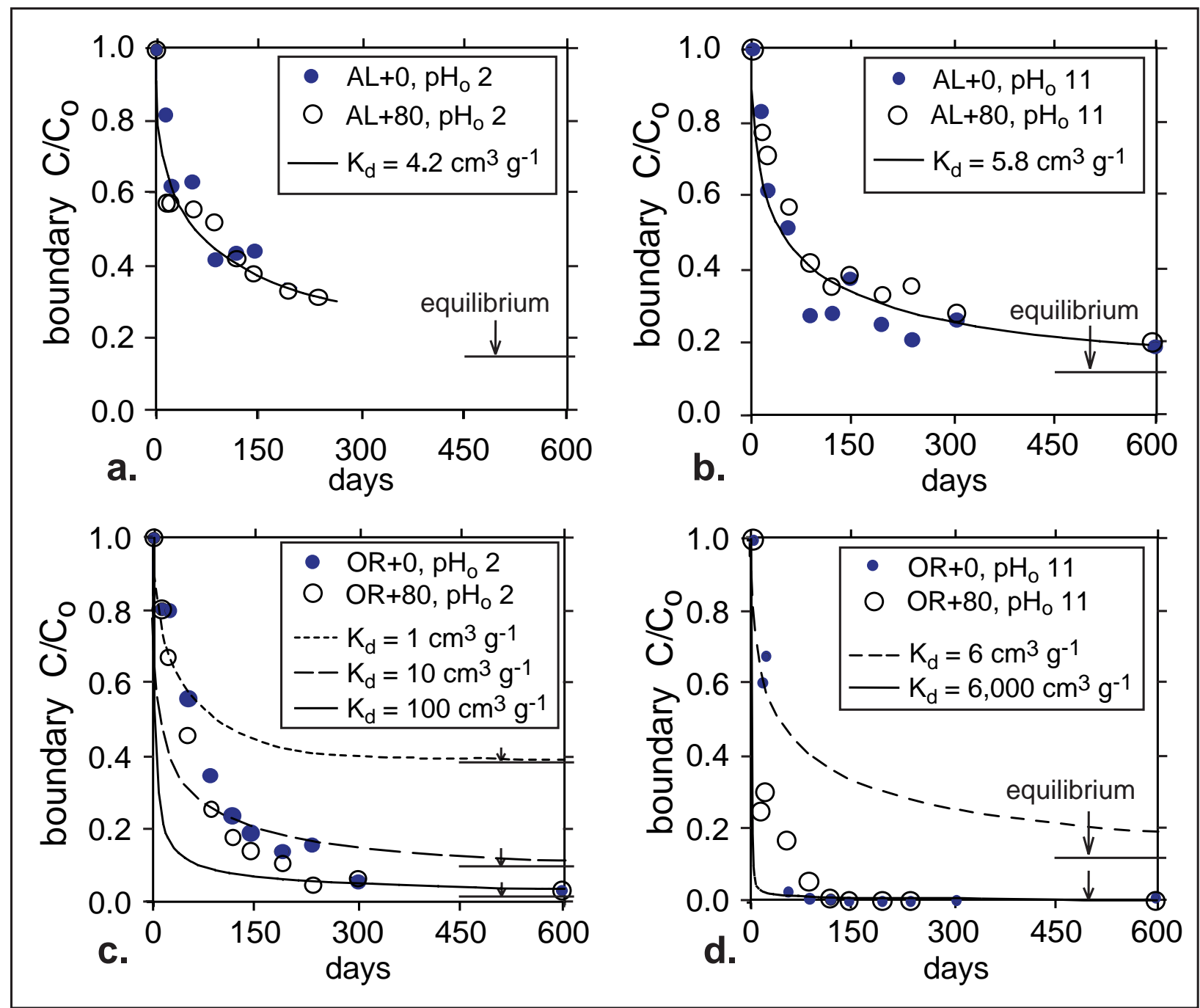

Figure 4. Time trends for reservoir $U$ concentrations. Individual graphs are for (a) Altamont soil with $\mathrm{pH}_{\mathrm{o}} 2.0$, (b) Altamont soil with $\mathrm{pH}_{\circ} 11.0$, (c) Oak Ridge soil with $\mathrm{pH}_{\circ}$ 2.0, and (d) Oak Ridge soil with $\mathrm{pH}_{\mathrm{o}} 11.0$. 


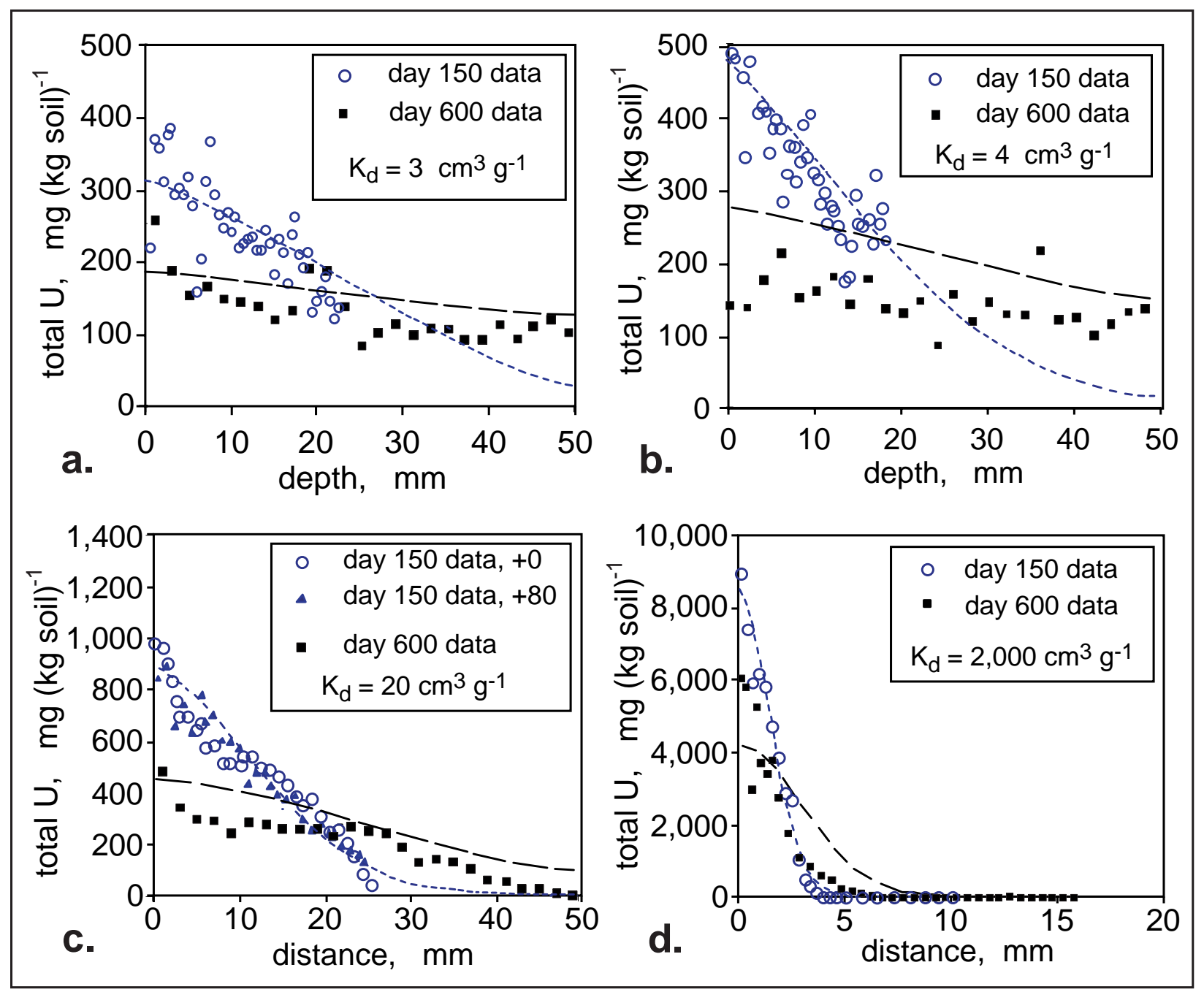

Figure 5. $\mathrm{U}(\mathrm{VI})$ concentration profiles within soil columns at 150 and 600 days, along with fits to eq 9. Individual graphs are for (a) Altamont soil with $\mathrm{pH}_{\circ} 2.0$, (b) Altamont soil with $\mathrm{pH}_{\mathrm{o}}$ 11.0, (c) Oak Ridge soil with $\mathrm{pH}_{\circ} 2.0$, and (d) Oak Ridge soil with $\mathrm{pH}_{\circ} 11.0$. 